\title{
Cyclin D1 expression in multiple myeloma by immunohistochemistry: Case series of 14 patients and literature review
}

\author{
Somanath Padhi, \\ Renu G'Boy Varghese, \\ Anita Ramdas
}

Department of Pathology, Pondicherry Institute of Medical Sciences, Puducherry, India

This manuscript was presented as an Oral Paper at the First Asian Clinical Congress, held at Bangkok, Thailand, on $29^{\text {th }}$ of January 2013.

\footnotetext{
Address for correspondence: Dr. Somanath Padhi, Department of Pathology, Pondicherry Institute of Medical Sciences, Ganapathychettykulam, Kalapet, Puducherry - 605014 , India.

E-mail: somanath.padhi@gmail.com
}

\begin{abstract}
A B S T R A C T
Background: Cyclin D1 dysregulation is an early and unifying oncogenic event in patients of multiple myeloma (MM). This may be detected up to $30 \%$ cases by immunohistochemistry $(\mathrm{IHC})$ and up to $40-50 \%$ cases by molecular studies. However, studies on the clinical significance of cyclin D1 dysregulation in MM have been inconclusive. We aimed to study the pattern of cyclin D1 expression in MM by IHC and correlate with selected clinicopathologic features. Materials and Methods: Formalin fixed, decalcified, bone marrow trephine sections from 14 symptomatic patients of MM (13 newly diagnosed and one relapsed) were subjected to cyclin D1 IHC by using a rabbit monoclonal antibody to cyclin D1 (clone EPR2241). Results: Cyclin D1 expression (in $\geq 10 \%$ tumor cell nuclei) was observed in 8 of 14 cases $(57 \%)$. Cyclin D1 positive $(+)$ group had significantly lower hemoglobin level $(P=0.03)$ than cyclin D1 negative $(-)$ group $(n=6)$; though both groups showed no statistical significance $(P>0.05)$ in regard to age, gender, Durie and Salmon stage, lytic bone lesions, light chain phenotype, creatinine, calcium, lactate dehydrogenase, leukocyte and platelet count and bone marrow histology. Ten of 14 (71.5\%) showed a favorable response (follow-up; 7 days to 34 months) to thalidomide and/or bortezomib based chemotherapeutic regimen. Four of eight cyclin D1 + patients showed complete response, two had a partial response (PR) and two died of the disease; whereas $4 / 6$ cyclin D1 - patients had PR, one refused definitive therapy and one was lost to follow-up $(P>0.05$, Fischer's exact test). Conclusion: IHC may be a feasible tool for the demonstration of cyclin D1 expression on adequately processed trephine biopsy specimen in MM patients in a resource poor setting. Negative IHC results should be correlated with molecular techniques for prognostication.
\end{abstract}

Key words: Bone marrow, cyclin D1, immunohistochemistry, multiple myeloma, prognosis

\section{INTRODUCTION}

Multiple myeloma (MM) is a neoplastic plasma cell disorder that is characterized by clonal proliferation of malignant plasma cells in the bone marrow microenvironment, monoclonal protein in serum and/or urine and associated organ dysfunction. This accounts for approximately $1 \%$ of neoplastic diseases and $13 \%$ of all hematologic malignancies. The median age at diagnosis is approximately 70 years; $37 \%$ of patients are younger than 65 years,

\begin{tabular}{|l|l|}
\hline \multicolumn{2}{|c|}{ Access this article online } \\
\hline Quick Response Code: & Website: \\
\hline & www.jmpo.org \\
\cline { 2 - 2 } & \\
\hline
\end{tabular}

$26 \%$ are between the ages 65 and 74 years and $37 \%$ are 75 years of age or older. ${ }^{[1]}$ The diagnosis is based upon the combination of clinicopathological, radiological and biochemical parameters. ${ }^{[1-3]}$

Cyclin D1 is a product of CCND1 gene which, in association with cyclin dependent kinase, causes phosphorylation of retinoblastoma gene product leading to release of the transcription factor E2F. This in turn, causes G1 to S phase transition allowing DNA replication and increased cellular proliferation. Overexpression of cyclin D1 by either translocation $\mathrm{t}(11 ; 14)$ ( $13 ; \mathrm{q} 32)$ (most common) or gene amplification is an early and unifying oncogenic event in several human cancers, most commonly mantle cell lymphoma and MM. Gene expression profiling and fluorescence in-situ hybridization (FISH) studies have identified prognostically significant and diverse genotypic variants of $\mathrm{MM}^{.[4-7]}$ Essentially, all cases of myeloma are associated with dysregulation of cyclin D1, D2 or 
D3 expression, which may have prognostic significance. Cases with dysregulation of cyclin D1 or D3 have been associated with a favorable prognosis compared with cyclin D2 positive cases. ${ }^{[8]}$ Although, most studies dealing with the prognostic significance of cyclin D1 in MM have been performed by using cell lines, microarrays or FISH techniques; recent studies have shown the utility of immunohistochemistry (IHC) in the prognostic evaluation in myeloma. ${ }^{[8-13]}$

The aim of the present study was to evaluate the immunohistochemical expression of cyclin D1 in a series of myeloma patients and correlate with clinicopathological features along with a brief review of relevant literature.

\section{MATERIALS AND METHODS}

We evaluated bone marrow aspirate and trephine biopsy specimen from 14 patients of MM (13 newly diagnosed and one at relapse) in the Department of Pathology of our Institute from January 2011 to September 2012. The Institutional Ethics Committee of our Institute approved the research study and in all, informed consent was obtained from the patients or their relatives in accordance with the Declaration of Helsinki. The diagnosis of MM was based upon a combination of pathological, radiological, biochemical and clinical features. ${ }^{[3]}$ All patients were staged according to the Durie and Salmon classification system. ${ }^{[14]}$ The parameters analyzed were: Age, gender, Durie and Salmon stage, presence and extent of lytic bone lesions, organomegaly, hemoglobin $(\mathrm{Hb}, \mathrm{g} / \mathrm{L})$, total leukocyte count $\left(\times 10^{9} / \mathrm{L}\right)$, total platelet count $\left(\times 10^{9} / \mathrm{L}\right)$, serum creatinine $(\mathrm{mg} / \mathrm{dL})$, total protein $(\mathrm{g} / \mathrm{dL})$, albumin $(\mathrm{g} / \mathrm{dL})$, albumin to globulin ratio (A:G; $<1 />1$ ), serum electrophoresis findings (cellulose acetate, $\mathrm{pH}=8.6$ ), corrected calcium $(\mathrm{mg} / \mathrm{dL})$, lactate dehydrogenase (LDH, IU/L) and light chain phenotype ( $\mathrm{k}$ or $\lambda$ ). Bone marrow trephine biopsy was fixed in $10 \%$ neutral buffered formalin, decalcified by sodium citrate-formic acid and then routinely stained with hematoxylin and eosin, Periodic acid Schiff and Grocott's silver impregnation technique. Wright-Giemsa stained bone marrow aspirate smears and trephine biopsy sections were then evaluated independently by three authors (SP, $\mathrm{RGV}, \mathrm{AR}$ ) for the myeloma cells (percentage of 500 nucleated cells); their cytomorphology (mature, small cell/lymphoplasmacytoid type - Grade I, intermediate/ immature - Grade II, blastic/pleomorphic - Grade III); the presence or the absence of cytoplasmic (crystalline, Russell bodies) and/or intra-nuclear inclusions (Dutcher body); pattern of marrow infiltration (interstitial/diffuse/ nodular/paratrabecular); histologic stage (extent of bone marrow infiltration by myeloma cells) (less than $20 \%$ stage I, $20-50 \%$ - stage II, or $>50 \%$ - stage III). ${ }^{[15]}$ As per the protocol, 12 out of 14 patients received drugs such as thalidomide (Th), dexamethasone, bortezomib $(\mathrm{Bz})$, melphalan, vincristine, doxorubicin/adriamycin or prednisolone in varying combinations; one received chemoradiotherapy; whereas one patient refused any definitive therapy. Th based regimen was used in $6, \mathrm{Bz}$ in 3 and Th-Bz combination in two patients. The follow-up $(n=12)$ period ranged from 7 days to 34 months. The response to therapy was described as complete response (CR), partial response (PR), no response or progression of disease using the European group bone marrow transplantation criteria. ${ }^{[16]}$

\section{Cyclin D1 IHC}

Four micron thick deparaffinized bone marrow trephine biopsy sections were subjected to cyclin D1 IHC by manual method using rabbit monoclonal antibody to cyclin D1 (clone EPR2241, predilluted, Biogenex, Hyderabad, India) (avidin-biotin-peroxidase complex method). Antigen retrieval was done by prior heating the tissue sections in a Pascal pressure cooker in $0.01 \mathrm{M}$ citrate buffer $(\mathrm{pH}=6)$ for 10-15 min. After the development of chromogen, all slides were counterstained with Hematoxylin. All three authors (SP, RGV, AR) who were blinded for the clinical features, evaluated the staining pattern under $\times 400$ magnification in Olympus CX 41 microscope (Malaysia). As proposed by others, ${ }^{[13,17]}$ only nuclear positivity, in at least $10 \%$ of myeloma cell nuclei, was considered as positive. The positive reaction was then graded semi-quantitatively as $1+(10-19 \%$ nuclei positive $), 2+(20-50 \%$ nuclei positive $)$ or $3+(>50 \%$ nuclei positive); and each positive reaction was further characterized as strong, intermediate or weak intensity. Lymph node sections from a patient with mantle cell lymphoma were taken as a positive control for cyclin D1 IHC; whereas sinusoidal endothelial cell positivity to cyclin D1 (in bone marrow) served as positive internal control. The pattern of cyclin D1 expression was correlated with the clinico hematologic parameters.

\section{Statistical analysis}

Based on the pattern of expression, the patients were divided in two subgroups such as cyclin D1 positive (cyclin $\mathrm{D} 1+$ ) and cyclin D1 negative (cyclin D1-). Comparison of variables between two groups was performed by using independent $t$-test, Mann-Whitney $U$-test and Fisher's exact test. $P \leq 0.05$ was considered to be statistically significant and Statistical Package for the Social Sciences-16 software (IBM SPSS Inc, Chicago, USA) was used for analysis.

\section{RESULTS}

The clinicopathologic characteristics of all 14 patients with MM (13 newly diagnosed, 1 relapsed) are presented in 
Table 1 . There were 11 males and 3 females with age range of 38-81 years $($ mean $=54$ years, standard deviation $=$ 10.7); and all were symptomatic at the time of evaluation. Eight (57\%) were in Durie and Salmon Stage II, 5 (37\%) Stage III and $1(7 \%)$ in Stage I. Out of 14 cases, 10 $(71.5 \%)$ presented with advanced lytic bone lesions, and two had organomegaly (one of which was de novo plasma cell leukemia). All, except one, had demonstrable light chain restriction $\left(7^{\prime} \mathrm{K}\right.$ ', 6 ' $\lambda$ ') by either IHC or biochemical assay techniques. Corrected serum calcium was found to be within normal range $(\leq 11 \mathrm{mg} / \mathrm{dL})$ in the majority of patients. On bone marrow evaluation, 10/14 (71\%) cases showed an interstitial pattern of infiltration with or without focal nodularity; and $4(29 \%)$ had packed marrow (diffuse pattern). Out of 14 cases, 10 (71\%) cases were in Bartl's histologic Stage III ( $>50 \%$ tumor cells); and in 7 (50\%), myeloma cells exhibited a high grade (blastic or pleomorphic) phenotype. Intracytoplasmic (Russell bodies) and intranuclear (Dutcher bodies) were noted in $11 / 13$ patients; and in two intracytoplasmic crystalline inclusions were seen [Figures 1a-g].

Cyclin D1 nuclear expression was noted in 8/14 (57\%) by means of IHC. In three cases (Case no. 1, 3, 7), the expression was of strong intensity, in $\geq 50 \%$ tumor cells; it was of intermediate to strong intensity in $20-50 \%$ cells in another three cases (Case no. 2, 6, 14); whereas weak nuclear positivity in 10-20\% cells was observed in remainder (Case no. 4, 8) [Figures $2 \mathrm{a}-\mathrm{d}$ ]. Of 8 cyclin D1+ patients, $4(50 \%)$ showed CR (1 with strong intensity, 3 with intermediate to strong intensity of reaction), 2 (25\%) had PR to chemotherapy (both with weak intensity of reaction); and 2 died of the disease (both with strong intensity reaction). On the other hand, 4/6 (67\%) cyclin D1- patients showed $\mathrm{PR}$, one refused any definite therapy and the other one was lost to follow-up [Table 2]. Among cyclin D1+ group, the duration of follow-up ranged from 7 days (Case 1,3+ strong intensity reaction, expired) to 34 months (Case 2, 2+ strong intensity reaction, $\mathrm{CR}$, alive) (mean $=9.4$ months) compared to cyclin D1- group (follow-up duration; 10-18 months) ( $P$ $>0.05$ ) [Tables 2 and 3].

Cyclin D1+ group had significantly lower $\mathrm{Hb}$ level $(P=$ $0.03)$ than cyclin D1- group; though both groups showed no statistical significance $(P>0.05)$ in regard to age, gender, Durie and Salmon stage, lytic bone lesions, light chain phenotype, creatinine, calcium, LDH, leukocyte and platelet count and bone marrow histology [Table 3].

\section{DISCUSSION}

We observed a higher percentage of cyclin D1 expression $(57 \%)$ in patients with MM by using IHC on bone

\begin{tabular}{|c|c|}
\hline \multicolumn{2}{|c|}{$\begin{array}{l}\text { Table 1: Clinicopathological parameters of } 14 \\
\text { patients of multiple myeloma (January } 2011 \\
\text { to September 2012) }\end{array}$} \\
\hline Parameters & Results (\%) \\
\hline Mean age (years) $\pm S D$ & $54 \pm 10.7$ \\
\hline Gender (male/female) & $11 / 3$ \\
\hline \multicolumn{2}{|l|}{ Durie and Salmon stage } \\
\hline I & $1 / 14(7)$ \\
\hline$\|$ & $8 / 14(57)$ \\
\hline III & $5 / 14(36)$ \\
\hline \multicolumn{2}{|l|}{ Organomegaly } \\
\hline Absent & $12 / 14(86)$ \\
\hline Present $^{\ddagger}$ & $2 / 14(14)$ \\
\hline \multicolumn{2}{|l|}{ Bone lesions } \\
\hline Present & $10 / 14(72)$ \\
\hline Absent & 4/14 (28) \\
\hline Secretory/non-secretory & $13 / 1$ \\
\hline Light chain $(\kappa / \lambda)(n=13)$ & $7 / 6$ \\
\hline \multicolumn{2}{|l|}{ Hemoglobin (g/L) } \\
\hline$<85$ & $8 / 14(57)$ \\
\hline$\geq 85$ & $6 / 14(43)$ \\
\hline \multicolumn{2}{|l|}{ Total platelet count $\left(\times 10^{9} / \mathrm{L}\right)$} \\
\hline$\leq 150$ & $5 / 14(36)$ \\
\hline$>150$ & $9 / 14(64)$ \\
\hline \multicolumn{2}{|l|}{ Corrected calcium (mg/dL) } \\
\hline$\leq 10$ & $9 / 14(64)$ \\
\hline$>10$ & $5 / 14(36)$ \\
\hline \multicolumn{2}{|l|}{ Albumin (g/dL) } \\
\hline$<3.5$ & $10 / 14(71)$ \\
\hline$\geq 3.5$ & 4/14 (29) \\
\hline \multicolumn{2}{|l|}{ Creatinine (mg/dL) } \\
\hline$<2$ & $7 / 14(50)$ \\
\hline$\geq 2$ & $7 / 14(50)$ \\
\hline \multicolumn{2}{|l|}{ A:G ratio } \\
\hline$<1$ & $12 / 14(86)$ \\
\hline$\geq 1$ & 2/14 (14) \\
\hline \multicolumn{2}{|c|}{ Lactate dehydrogenase (IU/L) ( $n=13)$} \\
\hline$\leq 500$ & 4/13(31) \\
\hline$>500$ & $9 / 13(69)$ \\
\hline \multicolumn{2}{|l|}{ Bartl's histological grade } \\
\hline Low (mature) & $1 / 14(7)$ \\
\hline Intermediate (immature) & $6 / 14(43)$ \\
\hline High (blastic/pleomorphic) & $7 / 14(50)$ \\
\hline \multicolumn{2}{|l|}{$\begin{array}{l}\text { Bartl's histological stage (\% of } \\
\text { plasma cells) }\end{array}$} \\
\hline$<20(\mathrm{l})$ & o \\
\hline $20-50$ (II) & 4/14 (29) \\
\hline$>50(I I I)$ & $10 / 14(71)$ \\
\hline \multicolumn{2}{|l|}{ Pattern of marrow infiltration } \\
\hline $\begin{array}{l}\text { Interstitial with or without } \\
\text { nodularity }\end{array}$ & $10 / 14(71)$ \\
\hline Diffuse & 4/14 (29) \\
\hline \multicolumn{2}{|l|}{ Response to therapy $(n=12)$} \\
\hline Yes & $10 / 12(83)$ \\
\hline No & $2 / 12(17)$ \\
\hline
\end{tabular}

${ }^{\ddagger}$ One with de novo plasma cell leukemia; SD - Standard deviation 
marrow trephine sections; and in 6/14 (43\%), the results were negative. Recent studies have demonstrated that translocations involving the immunoglobulin heavy chain gene locus $(14 \mathrm{q} 32)$ are the most frequent chromosomal aberrations in MM. The partner chromosomes in most cases are $11 \mathrm{q} 13$ (in the region of the bcl-1 gene) and less commonly 8q24, 18q21.3, 4p16.3 and 16q23..$^{[4,5]}$ The negative expression in other six patients in our series, might be explained by the fact that pathogenetic events other than $\mathrm{t}(11 ; 14)$ (q13;q32) such as RB gene deletion, abrogation of $\mathrm{G} 1 / \mathrm{S}$ phase might be responsible. However, none of our cases were subjected to any molecular analysis to substantiate this finding. Besides these, we did not find any cyclin D1+ resident hematopoietic cells in any of the bone marrow tissue sections analyzed by IHC; thus suggesting the specificity of this analysis. Moreover, another advantage of cyclin

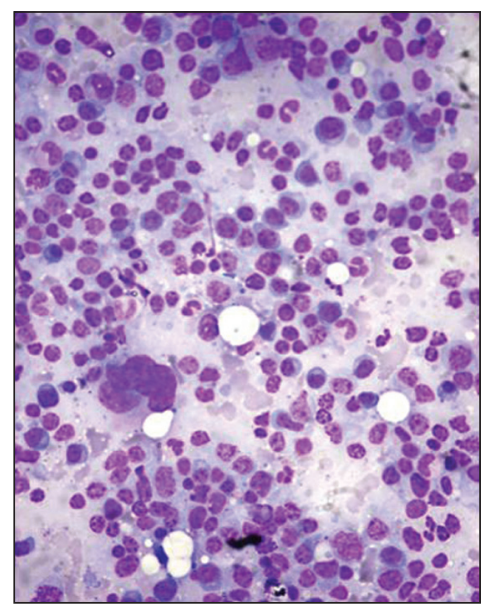

Figure 1a: Bone marrow aspirate smears from patients with myeloma showing mature (grade 1) myeloma cells. Note the small cell/ lymphoplasmacytic morphology in some (Wright-Giemsa, ×100)

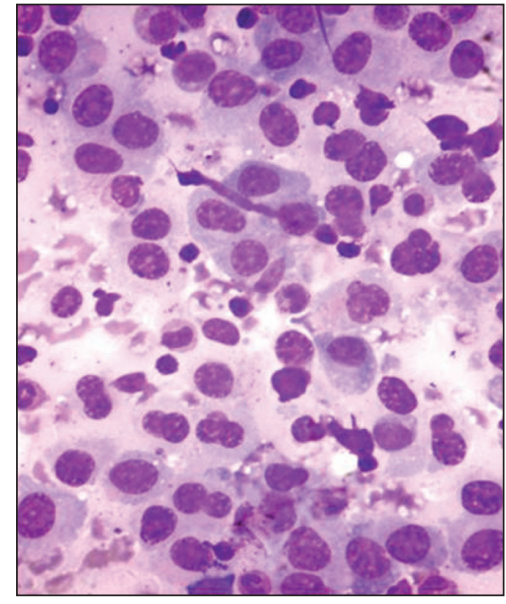

Figure 1c: Bone marrow aspirate smears from patients with myeloma showing pleomorphic myeloma cells/plasmablasts (grade III). These cells are characterized by high nuclear to cytoplasmic ratio, polylobated nuclei with prominent nucleoli (Wright-Giemsa, $\times 400$ )
D1 IHC is its ready availability in most of the laboratories at an affordable cost.

Recent studies have confirmed the impact of several molecular markers on survival of MM patients. Immunohistochemical staining for proteins implicated in MM pathogenesis is useful for the evaluation of the activity of the relative genes. Majority of MM patients have deregulated at least one of the cyclin genes (D1, D2, D3), suggesting that this may have prognostic value. ${ }^{[18]}$ However, a correlation between cyclin D1 expression, clinical parameters, histologic stage and the degree of differentiation of neoplastic plasma cells (histologic grading) has been reported only in a small series of patients. ${ }^{[13,17,19-24]}$

With IHC, cyclin D1 expression may be detected up to 25$35 \%$ and in up to $45-50 \%$ cases by FISH/polymerase chain

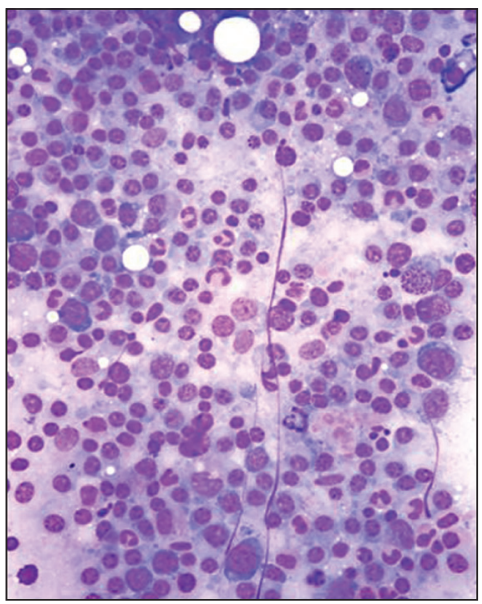

Figure 1b: Bone marrow aspirate smears from patients with myeloma showing admixture of mature (grade 1) and immature myeloma cells (those with increased nuclear to cytoplasmic ratio, grade II) (WrightGiemsa, ×400)

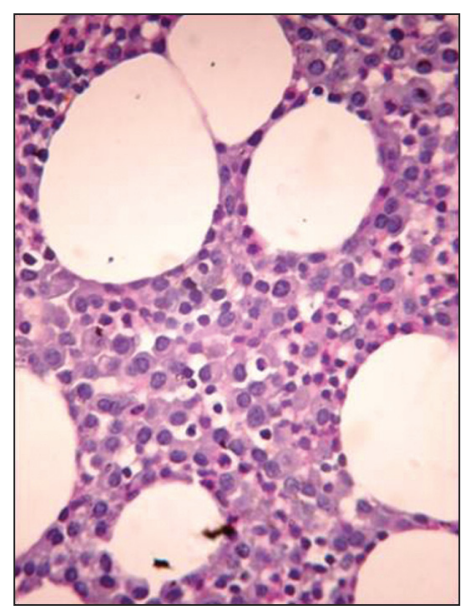

Figure 1d: Hematoxylin and eosin stained bone marrow trephine sections showing interstitial pattern of infiltration by myeloma cells $(\times 400)$ 


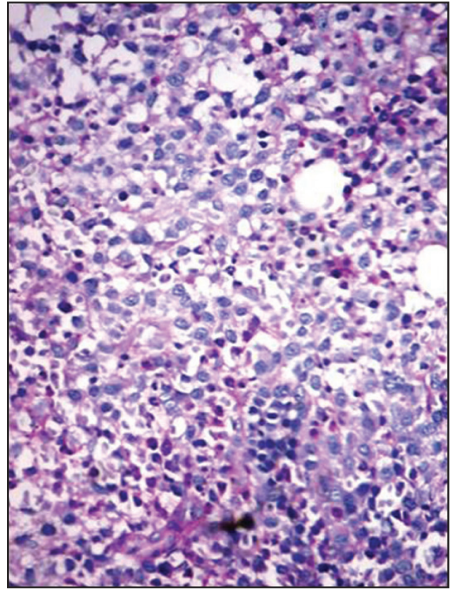

Figure 1e: Periodic acid Schiff (PAS) stained bone marrow trephine sections showing a diffuse pattern of infiltration by myeloma cells (packed marrow) $(\times 400)$

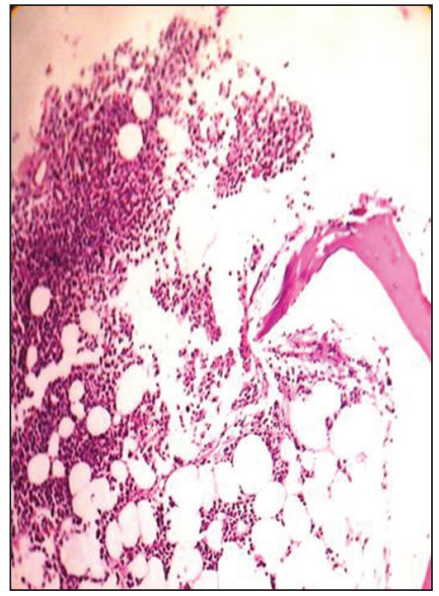

Figure 1f: Hematoxylin and eosin stained bone marrow trephine sections showing a nodular pattern of infiltration by myeloma cells $(\times 100)$

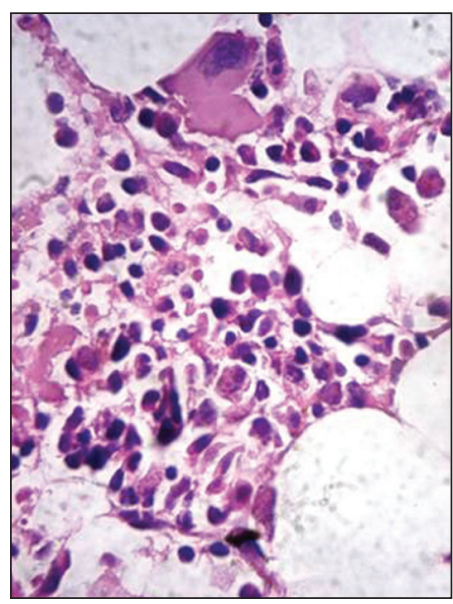

Figure 1g: Presence of intracytoplasmic crystalline inclusions in myeloma cells $(\mathrm{H}$ and $\mathrm{E}, \times 400)$

reaction/microarray techniques. The difference in level of expression, as observed by various authors, may be due to type of case selection (new or relapsed/refractory patients), cut-off percentage of nuclear positivity taken $(\geq 10 \%$ in most series) and sensitivities of the assay technique used. In our series, strong to intermediate intensity of nuclear positivity was noted in six patients and in remainders two, it was weak in intensity. All were symptomatic at the time of evaluation; a higher proportion of them were in Durie-Salmon Stage II/III (8/5) with advanced lytic bone lesions (10/14); most of them had a preponderance toward immature $(n=6)$ to blastic phenotype $(n=7)$ and greater extent of marrow infiltration (10/14, Stage III); all indicative of increased tumor burden or progression of the disease process [Table 1]. Compared to cyclin D1- group (4/6 PR), 4/8 cyclin D1+ patients achieved CR, 2 had PR; and remainder 2 died of the disease; though there was discordance between the intensity of reaction and response to therapy [Table 2]. However, in view of a very small series of patients and smaller follow-up period, the outcome of analysis was statistically insignificant [Table 3].

A comparative review of literature describing the correlation between cyclin D1 expression and clinicopathological features in myeloma is presented in Table 4. Previous studies have described a strong positive association between cyclin D1 expression with advanced clinical stage, higher histologic stage and grade, increased proliferative activity (plasma cell labeling index), impaired renal functions and higher $\beta 2$ microglobulin levels. ${ }^{[10,11,17,20-24]}$ However, other studies in this context have shown conflicting results. ${ }^{[8,13,19]}$ A recent study, ${ }^{[8]}$ recruited including 94 myeloma patients, and found no difference in the pattern of expression in a newly diagnosed $(n=49)$ and relapsed/refractory $(n=45)$ myeloma which was consistent with the observation that nearly all subsets of myeloma eventually relapse with current treatment protocol. Moreover, no significant association was found with the degree of expression and clinicopathologic features in that study. Similarly, in another series of 59 newly diagnosed myeloma patients, cyclin D1 positivity or negativity did not convey any significant correlation with clinicopathological features or survival. ${ }^{[19]}$ Hoyer et al. analyzed 24 cases of MM, of which 10 had a lymphoplasmacytoid morphology and 4 were in leukemic phase. On IHC, strong cyclin D1 positivity was noted in $19 / 24$ and all 19 patients died with the disease. ${ }^{[21]}$

Cook et al. described two prognostically favorable subgroups of cyclin D1+ myeloma patients by means of IHC and FISH. ${ }^{[13]}$ Strong cyclin D1 immunostaining was associated with a higher percentage of myeloma cells at diagnosis $($ median $=60 \%$ ), distinct lymphoplasmacytoid morphology, strong CD20 expression and t $(11 ; 14)$ (q13; 32) translocation (by FISH). In contrast, weak staining was associated with hyperdiploid karyotype and gain of CCND1 locus. Although both subgroups showed distinct histomorphological patterns, both experienced a 


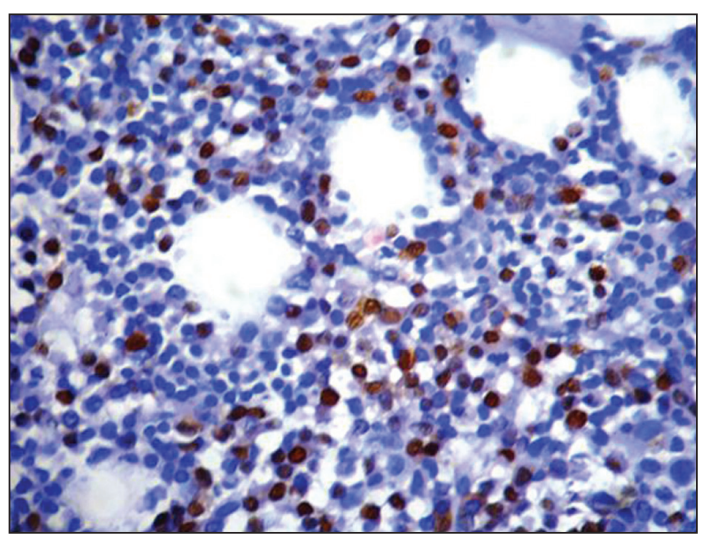

Figure 2a: Pattern of cyclin D1 expression in multiple myeloma. Strong nuclear positivity in greater that $50 \%$ tumor cells $(3+)$ (Peroxidaseantiperoxidase stain, $\times 400$ )

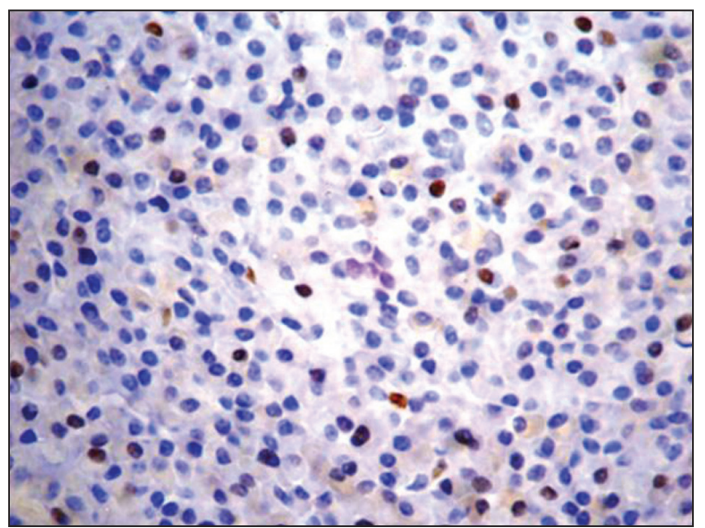

Figure 2c: Weak to intermediate nuclear positivity in $10-20 \%$ tumor cells $(1+)$ (Peroxidase-antiperoxidase stain, $\times 400)$

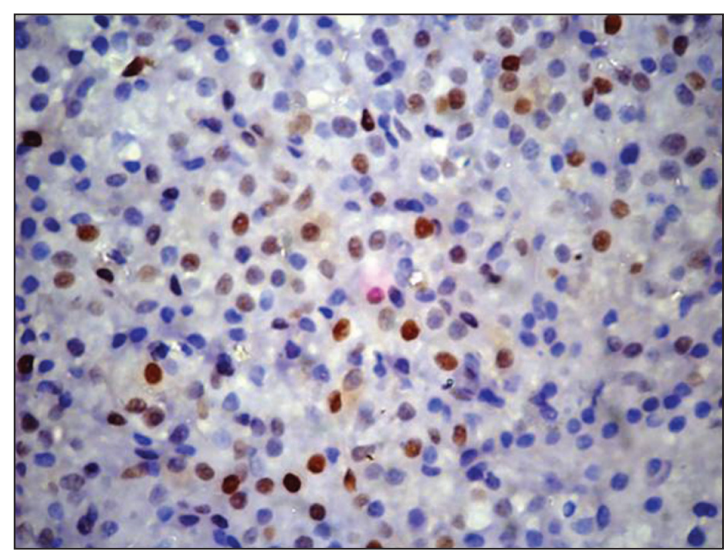

Figure $2 \mathrm{~b}$ : Intermediate to strong nuclear positivity in $30-50 \%$ tumor cells $(2+)$ (Peroxidase-antiperoxidase stain, $\times 400)$

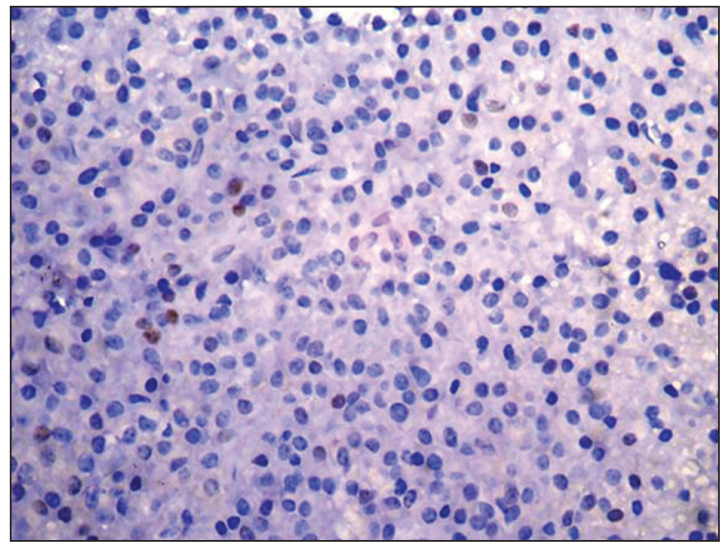

Figure 2d: Weak nuclear positivity in less than $10 \%$ tumor cells (negative) (Peroxidase-antiperoxidase stain, $\times 400$ )

\begin{tabular}{|c|c|c|c|c|c|c|c|}
\hline $\begin{array}{l}\text { Case } \\
\text { no. }\end{array}$ & $\begin{array}{l}\text { Age (years)/ } \\
\text { gender }^{+}\end{array}$ & DS stage & $\begin{array}{c}\text { Bartl's } \\
\text { histologic stage }\end{array}$ & $\begin{array}{c}\text { Cyclin D1 } \\
\text { expression" }\end{array}$ & Therapy $^{\ddagger}$ & Outcome ${ }^{[16] \|}$ & Follow-up period \\
\hline 1 & $38 / \mathrm{F}$ & IIIB & III & $3^{+}$, strong & $B z+D x+A b$ & $\begin{array}{l}\text { NR, death due to } \\
\text { sepsis and MOF }\end{array}$ & 7 days \\
\hline 2 & 46/M & IIB & III & $2+$, strong & Th+Dx & Relapse and death & 34 months \\
\hline 3 & $65 / M$ & $\| \mathrm{A}$ & ॥ & Negative & $\mathrm{Mp}+\mathrm{Th}+\mathrm{Pn}$ & $\mathrm{PR}$, alive & 10 months \\
\hline 4 & $64 / M$ & IIIB & III & $1+$, intermediate & $B z+D x$ & $\mathrm{CR}$, alive & 4 months \\
\hline 5 & $50 / \mathrm{M}$ & $\mathrm{IA}$ & II & Negative & $R T+D x+T h$ & PR, alive & $\begin{array}{l}18 \text { months, then } \\
\text { lost to follow-up }\end{array}$ \\
\hline 6 & $69 / M$ & IIIB & III & $2+$, intermediate & $\mathrm{Bz}+\mathrm{Dx}$ & $\mathrm{CR}$, alive, $\mathrm{HZ}$, PTB & 10 months \\
\hline 7 & $55 / M$ & $\mathrm{IIB}$ & III & $3+$, strong & $\mathrm{Bz}+\mathrm{Th}+\mathrm{Dx}$, plasmapharesis & $C R$, alive & 12 months \\
\hline 8 & $62 / \mathrm{M}$ & $\| \mathrm{A}$ & II & $1+$, weak & $V+A+D x$ & PR & $\begin{array}{l}4 \text { months, then } \\
\text { lost to follow-up }\end{array}$ \\
\hline 9 & $81 / M$ & IIB & III & Negative & Dx+symptomatic & LAMA & - \\
\hline 10 & $50 / M$ & IIIA & III & Negative & $\mathrm{Dx}+\mathrm{Th}$ & $\mathrm{PR}$, alive & 17 months \\
\hline 11 & $60 / F$ & $\| A$ & II & Negative & $R T+D x+T h+P T$ & $\mathrm{PR}$, alive & 10 months \\
\hline 12 & $47 / M$ & IIB & III & Negative & Th+Dx & Lost to follow-up & - \\
\hline 13 & $60 / M$ & IIIA & III & $3^{+}$, strong & Symptomatic & $\mathrm{PR}$, alive & 7 months \\
\hline 14 & 40/F & $\| A$ & III & $2+$, intermediate & $T h+D x$ & $C R$, alive & 4 months \\
\hline
\end{tabular}

${ }^{\dagger} \mathrm{M}$ - Male; F-Female; ${ }^{*} 3^{+-}$- Greater than $50 \%$ nuclear positivity; $2+-20-50 \%$ nuclear positivity; ${ }_{1+-1}-10-19 \%$ nuclear positivity; Negative - Less than $10 \%$ nuclei positive; ${ }^{\prime} \mathrm{Bz}$ - Bortezomib; Th - Thalidomide; Dx - Dexamethasone; Ab-Antibiotics; Mp - Melphalan; Pn - Prednisolone; RT - Radiotherapy; V-Vincristine; A - Adriamycin/ doxorubicin; PT - Physiotherapy; "NR - No response; MOF - Multiorgan failure; PR - Partial response; CR - Complete response; HZ - Herpes zoster; PTB - Pulmonary tuberculosis; LAMA - Refused definitive therapy and left against medical advice 
Padhi, et al.: Cyclin D1 in multiple myeloma

\begin{tabular}{|c|c|c|c|}
\hline Parameters & Cyclin D1+ $(n=8)$ & Cyclin D1- $(n=6)$ & $P$ value $* * *$ \\
\hline Age (years) $\pm S D$ & $54.25 \pm 11.6$ & $58.83 \pm 12.8$ & 0.498 \\
\hline Male, female & 6,2 & 5,1 & \\
\hline \multicolumn{4}{|l|}{ Durie and Salmon stage (\%) } \\
\hline I/II & $4(50)$ & $5(83.3)$ & 0.301 \\
\hline III & $4(50)$ & $1(16.7)$ & \\
\hline \multicolumn{4}{|l|}{ Light chain phenotype ( $n=13)(\%)$} \\
\hline $\mathrm{k}$ & $3(42.9)$ & $4(66.7)$ & 0.383 \\
\hline$\lambda$ & $4(57.1)$ & $2(33.3)$ & \\
\hline \multicolumn{4}{|l|}{ Bone lesions (\%) } \\
\hline Present & $6(75)$ & $5(83.3)$ & 1.000 \\
\hline None & $2(25)$ & $1(16.7)$ & \\
\hline Hemoglobin (g/L) & $59 \pm 22.9$ & $88.5 \pm 23.2$ & 0.036 \\
\hline Total platelet count $\left(\times 10^{9} / \mathrm{L}\right)$ & $210(152.5)$ & $170(107.5)$ & 0.332 \\
\hline Total serum protein (g/L) & $8.087 \pm 2.1$ & $8.15 \pm 1.56$ & 0.952 \\
\hline Serum albumin (g/L) & $2.700 \pm 0.75$ & $2.88 \pm 1.1$ & 0.717 \\
\hline Calcium (mg/dL) & $9.66 \pm 0.81$ & $9 \cdot 38 \pm 1.28$ & 0.627 \\
\hline Creatinine (mg/dL) & $2.6(1.32)$ & $1.8(0.9)$ & 0.331 \\
\hline Lactate dehydrogenase (IU/L) $(n=13)$ & $620.4 \pm 272.85$ & $574 \cdot 3 \pm 71.6$ & 0.697 \\
\hline \multicolumn{4}{|c|}{ Marrow plasma cells (histologic stage) (\%) } \\
\hline$<50 \%$ & $1(12.5)$ & $1(16.7)$ & 0.154 \\
\hline$\geq 50 \%$ & $7(87.5)$ & $5(83 \cdot 3)$ & \\
\hline \multicolumn{4}{|l|}{ Histologic grade (\%) } \\
\hline Low/intermediate & $4(50)$ & $3(50)$ & 0.704 \\
\hline High & $4(50)$ & $3(50)$ & \\
\hline \multicolumn{4}{|l|}{ Pattern of infiltration (\%) } \\
\hline Interstitial & $5(62.5)$ & $6(100)$ & 0.209 \\
\hline Diffuse & $3(37.5)$ & o & \\
\hline \multicolumn{4}{|l|}{ Response to therapy ${ }^{[16]}(n=12)(\%)$} \\
\hline Complete response & $4(50)$ & - & 0.356 \\
\hline Partial response & $2(25)$ & $4(67)$ & \\
\hline No response & $2(25)$ & & \\
\hline Follow-up duration" & $\begin{array}{c}7 \text { days to } 34 \text { months (mean }=9.4 \\
\text { months) }\end{array}$ & 10-18 months & \\
\hline
\end{tabular}

superior/favorable survival over cyclin D1-group (3 year expected survival $73 \%$ vs. $27 \%$, respectively, $P=0.005)$.

The pathobiology of extramedullary plasmacytomas (EMP) may be quite distinct from MM. A recent Japanese study evaluated immunohistochemical expression of cyclin D1 in a series of 11 primary EMP (none with myelomatous transformation at the time of analysis). ${ }^{[11]}$ Out of 11 cases, $4(37 \%)$ were cyclin D1+ (>30\% tumor cell nuclei) and it was negative in remaining 7 cases. Five of 7 cyclin D1patients showed a well-differentiated morphology and all 7 achieved CR. In contrast, 2/4 cyclin D1+ cases showed high grade morphology and 3 died of the disease. This finding suggests that cyclin D1 expression may be an adverse prognostic indicator in EMP. However, most of the patients, in that series, received radiotherapy, either solely
$(5 / 11)$ or in combination with surgery/chemotherapy, which might have influenced the outcome.

The introduction of autologous stem cell transplantation (ASCT) and novel agents such as immunomodulators (Th, lenalidomide) and proteasome inhibitors like $\mathrm{Bz}$ have changed the management of myeloma patients and extended the overall survival (OS). ${ }^{[25]}$ Cyclin D1, D2 and D3 proteins are regulated by ubiquitin-proteasome mediated degradation. Cyclin D1 is rapidly degraded by the 26S proteasome and $\mathrm{Bz}$ increases its activity in vivo. Cyclin D1 levels inversely correlate with STAT-3 levels, resulting in downstream effects that increase the susceptibility of cells to apoptosis. ${ }^{[12]}$ Overexpression of cyclin D1 correlated with a durable response to and better prognosis to $\mathrm{Bz}$ therapy in small series of patients. ${ }^{[12,26]}$ On the other hand, 
Padhi, et al.: Cyclin D1 in multiple myeloma

\begin{tabular}{|c|c|c|c|c|c|c|}
\hline $\begin{array}{l}\text { Author, year, } \\
\text { number of cases }(n)\end{array}$ & $\begin{array}{l}\text { Type of } \\
\text { patients }^{+}\end{array}$ & Methods used ${ }^{\ddagger}$ & $\begin{array}{l}\text { Number } \\
\text { and } \\
\text { percentage } \\
\text { of positivity }\end{array}$ & $\begin{array}{l}\text { Histology (Bartl grade } \\
\text { and stage) })^{[15]}\end{array}$ & $\begin{array}{l}\text { Clinical stage } \\
\text { (Durie and } \\
\text { Salmon) }\end{array}$ & Remark $^{5}$ \\
\hline $\begin{array}{l}\text { Tasidou et al.. }{ }^{[10]} \\
2012,(115)\end{array}$ & $\begin{array}{l}\text { MM (ND), } \\
\text { symptomatic }\end{array}$ & IHC & 35/115 (30) & Not reported & $\begin{array}{l}\text { Higher clinical } \\
\text { stage (ISS)" }\end{array}$ & $\begin{array}{l}\text { Unfavorable to conventional } \\
\text { CT without ASCT }\end{array}$ \\
\hline $\begin{array}{l}\text { Kojima et al., }{ }^{[11]} \\
2009(11)\end{array}$ & Primary EMP & $\begin{array}{l}\mathrm{IHC}(11 / 11) \mathrm{FISH} \\
(2 / 11)\end{array}$ & 4/11 (37) & $\begin{array}{l}\text { 6-gr l, 3-gr II, 2-gr III, } \\
\text { 2-amyloid }\end{array}$ & - & Unfavorable outcome \\
\hline $\begin{array}{l}\text { Cook et al., }{ }^{[13]} 2006 \\
(44)\end{array}$ & $\mathrm{MM}(\mathrm{ND})$ & $\mathrm{IHC}$ & $\begin{array}{l}\text { 22/44 (50)i } \\
\text { 8-strong, } \\
\text { 14-weak }\end{array}$ & $\begin{array}{l}\text { Increased plasma cells, } \\
\text { lymphoplasmacytoid } \\
\text { morphology, CD 20+ }\end{array}$ & - & $\begin{array}{l}\text { Favorable outcome, strong } \\
\text { correlation with t (11; } \\
14 \text { [q13; } \mathrm{q}_{2} \text { ]) }\end{array}$ \\
\hline $\begin{array}{l}\text { Athanasiou et al., }{ }^{[17]} \\
2001(71)\end{array}$ & $\begin{array}{l}\mathrm{MM}(62 \mathrm{ND}, \\
9 \mathrm{R})\end{array}$ & IHC ISH & $\begin{array}{l}17 / 71(24) \\
23 / 71(32) \text { by } \\
\text { ISH }\end{array}$ & $\begin{array}{l}38 / 71 \text { - gr I, 23/71 - gr } \\
\text { II, } 10 / 71 \text { - gr III, 35/71 - } \\
\text { stage III, 20/71 - stage II }\end{array}$ & - & $\begin{array}{l}\text { Positive correlation with } \\
\text { higher histologic grade and } \\
\text { stage }\end{array}$ \\
\hline $\begin{array}{l}\text { Markovic et al., }{ }^{[19]} \\
2004 \text { (59) }\end{array}$ & $\mathrm{MM}(\mathrm{ND})$ & $\mathrm{IHC}$ & $14 / 59(27)$ & $\begin{array}{l}\text { 31/59 - gr I, 21/59 - gr II, } \\
\text { 7/59 - gr III; 32/59 - stage } \\
\text { II, 21/59 - stage III }\end{array}$ & 39 stage III & $\begin{array}{l}\text { No correlation with } \\
\text { clinicopathological features } \\
\text { and outcome }\end{array}$ \\
\hline $\begin{array}{l}\text { Pruneri et al., }{ }^{[20]} \\
2000(48)\end{array}$ & $\begin{array}{l}40 \mathrm{ND}, 8 \\
\mathrm{R}, 22 / 40 \\
\text { symptomatic }\end{array}$ & IHC FISH (39 cases) & $\begin{array}{l}\text { 12/48 (25), } \\
7 / 39(18) \text { by } \\
\text { FISH }\end{array}$ & $\begin{array}{l}29 / 40 \text { - gr l, 9/40 - gr } \\
\text { II, 2/40 - gr III; } 20 / 40 \text { - } \\
\text { stage I, 11/40 - stage II, } \\
\text { 9/40 - stage III }\end{array}$ & $\begin{array}{l}23 / 40-1,11 / 40- \\
111,6 / 40-11\end{array}$ & $\begin{array}{l}\text { Positive correlation with } \\
\text { clinical and histologic stage }\end{array}$ \\
\hline $\begin{array}{l}\text { Hoyer et al.. }{ }^{[22]} 2000 \\
(24)\end{array}$ & $\begin{array}{l}20 \mathrm{MM} \text {, } \\
4 \mathrm{PCL} \\
24 / 24 \text { bone } \\
\text { lesions+ }\end{array}$ & IHC, GTG banding & $19 / 24(79)$ & $\begin{array}{l}13 / 24 \text { - gr I/II, } 10 / 24 \text { - } \\
\text { lymphoplasmacytoid, } \\
1 / 24 \text { - gr III; median } \\
\text { stage - II (6o\% myeloma } \\
\text { cells), high PCLI (16/24) }\end{array}$ & - & $\begin{array}{l}\text { Unfavorable, } \mathrm{t}(11 ; 14) \\
\text { (q13; } 932) \text {-more at relapse }\end{array}$ \\
\hline $\begin{array}{l}\text { Vollmar et al.. }{ }^{[22]} \\
2000(50)\end{array}$ & $\begin{array}{l}37 \text { untreated } \\
\text { MM, } 13 \\
\text { treated }\end{array}$ & IHC+immunoblotting & $20 / 50(40)$ & $\begin{array}{l}28 / 50 \text { - gr I, 22/50 - gr } \\
\text { II; } 37 / 50 \text { - stage I/II } \\
13 / 50 \text { - stage III; PCLI >1 } \\
(24 / 50),<1(26 / 50)\end{array}$ & $\begin{array}{l}22 / 50-111 \\
20 / 50-I \\
8 / 50-11\end{array}$ & $\begin{array}{l}\text { Unfavorable, positive } \\
\text { correlation with tumor } \\
\text { burden }\end{array}$ \\
\hline $\begin{array}{l}\text { Present series, 2012, } \\
\text { (14) }\end{array}$ & $\begin{array}{l}\mathrm{MM}, 13 \mathrm{ND}, \\
1 \mathrm{R}\end{array}$ & $\mathrm{IHC}$ & $8 / 14(57)$ & $\begin{array}{l}\text { 7/14 - gr III, 6/14 - gr II, } \\
\text { 1/14 - gr I; 10/14 - stage } \\
\text { III, 4/14 - stage II; 10/14 - } \\
\text { interstitial pattern, 4/14 } \\
\text { - packed marrow }\end{array}$ & $\begin{array}{l}8 / 14-I I, 5 / 14- \\
I I I, 1 / 14-I\end{array}$ & $\begin{array}{l}\text { Cyclin D } 1+(4 / 8-C R, 2 / 8-P R, \\
2 / 8-\text { death); cyclin D1- } \\
(4 / 6 ; P R) ; \text { insignificant } \\
\text { correlation with clinical and } \\
\text { pathological features }\end{array}$ \\
\hline
\end{tabular}

${ }^{\dagger} \mathrm{MM}$ - Multiple myeloma; ND - Newly diagnosed; R - Relapse; EMP - Extramedullary plasmacytomia; PCL - Plasma cell leukemia. ${ }^{\ddagger} \mathrm{HC}$ - Immunohistochemistry; FISH Fluorescence in-situ hybridization; GTG - Giemsa Trypsin Giemsa; PCLI - plasma cell labelling index; IInternational system staging; ${ }^{\text {s }} \mathrm{CT}$ - Chemotherapy; ASCT - Autologous stem cell transplantation; CR - Complete response; PR - Partial response; gr - Grade; ISS - International System Staging for multiple myeloma

cyclin D1 expression conveyed an unfavorable prognosis in 115 newly diagnosed patients of symptomatic myeloma treated with $\mathrm{Bz}$ and/or Th based regimens; although ASCT were offered to a lesser number of patients. ${ }^{[10]}$ Another study evaluated the prognostic significance of cyclin kinase (CK) 1B nuclear expression in 60 relapsed/ refractory myeloma patients by IHC and FISH. ${ }^{[9]}$ There was no significant difference in response rate between patients with $(19 / 60)$ and without (41/60) CK $1 \mathrm{~B}$ expression. However, patients with CK $1 \mathrm{~B}$ expression had significant shorter progression free survival (PFS) and OS compared to those without CK 1B. In contrast, other studies did not find the prognostic significance of cyclin D1 and other markers on PFS and OS in newly diagnosed or relapsed/ refractory myeloma treated with Th based regimen. ${ }^{[8]}$ The discrepancy between above results may be explained by the difference in the study population (newly diagnosed or relapsed/refractory), therapeutic regimen used (with or without ASCT) and the duration of follow-up.

\section{SUMMARY AND FUTURE PERSPECTIVE}

Our observation suggests that cyclin D1 IHC performed on an adequate, appropriately processed trephine biopsy specimen may be a sensitive tool for the prognostic evaluation of myeloma patients in a resource poor setting and only negative results should be confirmed by molecular studies. Furthermore, cyclin D1 expression may have a favorable or at least, neutral prognostic impact on a subset of patients with myeloma. Small sample size, lack of correlation with molecular studies due to financial constraints and shorter duration of follow-up, were the major drawbacks of our study. Therefore, larger prospective studies in the near future is required to validate our observations; to compare the pattern of expression between newly diagnosed and at follow-up (after 6 months), as well as among newly diagnosed and relapsed patients. 
Padhi, et al.: Cyclin D1 in multiple myeloma

\section{ACKNOWLEDGMENT}

The authors sincerely thank Dr. Prathiba, M.D., Professor and Head of the Department of Pathology, Sri Ramachandra Medical University, Porur, Chennai, India, for her technical help in performing cyclin D1 IHC on bone marrow trephine sections; and Miss Bridgitte Ambrose of Pondicherry Institute of Medical Sciences for the statistical assistance.

\section{REFERENCES}

1. Palumbo A, Anderson K. Multiple myeloma. N Engl J Med 2011;364:1046-60.

2. McKenna RW, Kyle RA, Kuehl WM, Grogan TM, Harris NL, Coupland RW. Plasma cell neoplasm. In: Swerdlow SH, Campo E, Harris NL, Jaffe ES, Pileri SA, Stein $H$, et al., editors. WHO Classification of Tumors of Hematopoietic and Lymphoid Tissues. $4^{\text {th }}$ ed. Lyon: IARC; 2008. p. 200-12.

3. International Myeloma Working Group. Criteria for the classification of monoclonal gammopathies, multiple myeloma and related disorders: A report of the international myeloma working group. Br J Haematol 2003;121:749-57.

4. Zhan F, Huang Y, Colla S, Stewart JP, Hanamura I, Gupta S, et al. The molecular classification of multiple myeloma. Blood 2006;108:2020-8.

5. Bergsagel PL, Kuehl WM, Zhan F, Sawyer J, Barlogie B, Shaughnessy J Jr. Cyclin D dysregulation: An early and unifying pathogenic event in multiple myeloma. Blood 2005; 106:296-303.

6. Marsaud V, Tchakarska G, Andrieux G, Liu JM, Dembele D, Jost $\mathrm{B}$, et al. Cyclin $\mathrm{K}$ and cyclin $\mathrm{D} 1 \mathrm{~b}$ are oncogenic in myeloma cells. Mol Cancer 2010;9:103.

7. Krieger S, Gauduchon J, Roussel M, Troussard X, Sola B. Relevance of cyclin D1b expression and CCND1 polymorphism in the pathogenesis of multiple myeloma and mantle cell lymphoma. BMC Cancer 2006;6:238.

8. Kelley TW, Baz R, Hussein M, Karafa M, Cook JR. Clinical significance of cyclin D1, fibroblast growth factor receptor 3 , and p53 immunohistochemistry in plasma cell myeloma treated with a thalidomide-based regimen. Hum Pathol 2009;40:405-12.

9. Chen $\mathrm{MH}$, Qi C, Reece D, Chang $\mathrm{H}$. Cyclin kinase subunit 1B nuclear expression predicts an adverse outcome for patients with relapsed/refractory multiple myeloma treated with bortezomib. Hum Pathol 2012;43:858-64.

10. Tasidou A, Roussou M, Terpos E, Kastritis E, Gkotzamanidou $\mathrm{M}$, Gavriatopoulou $\mathrm{M}$, et al. Increased expression of cyclin-D1 on trephine bone marrow biopsies independently predicts for shorter overall survival in patients with multiple myeloma treated with novel agents. Am J Hematol 2012;87:734-6.

11. Kojima M, Motoori $T$, Tamaki $Y$, Igarashi $T$, Matsumoto $\mathrm{M}$, Shimizu K, et al. Cyclin D1 protein overexpression in extramedullary plasmacytoma: A clinicopathologic study of 11 cases. J Clin Exp Hematop 2009;49:53-6.

12. Dawson MA, Opat SS, Taouk $Y$, Donovan $M$, Zammit $M$, Monaghan K, et al. Clinical and immunohistochemical features associated with a response to bortezomib in patients with multiple myeloma. Clin Cancer Res 2009;15:714-22.

13. Cook JR, Hsi ED, Worley S, Tubbs RR, Hussein M.
Immunohistochemical analysis identifies two cyclin D1+ subsets of plasma cell myeloma, each associated with favorable survival. Am J Clin Pathol 2006;125:615-24.

14. Bataille R, Durie BG, Grenier J, Sany J. Prognostic factors and staging in multiple myeloma: A reappraisal. J Clin Oncol 1986;4:80-7.

15. Bartl R, Frisch B, Fateh-Moghadam A, Kettner G, Jaeger K, Sommerfeld W. Histologic classification and staging of multiple myeloma. A retrospective and prospective study of 674 cases. Am J Clin Pathol 1987;87:342-55.

16. Smith A, Wisloff F, Samson D, UK Myeloma Forum, Nordic Myeloma Study Group, British Committee for Standards in Haematology. Guidelines on the diagnosis and management of multiple myeloma 2005. Br J Haematol 2006;132:410-51.

17. Athanasiou $E$, Kaloutsi V, Kotoula V, Hytiroglou $P$, Kostopoulos I, Zervas C, et al. Cyclin D1 overexpression in multiple myeloma. A morphologic, immunohistochemical, and in situ hybridization study of 71 paraffin-embedded bone marrow biopsy specimens. Am J Clin Pathol 2001:116:535-42.

18. Yeung J, Chang H. Genomic aberrations and immunohistochemical markers as prognostic indicators in multiple myeloma. J Clin Pathol 2008;61:832-6.

19. Markovic O, Marisavljevic D, Cemerikic V, Suvajdzic N, Milic $\mathrm{N}$, Colovic M. Immunohistochemical analysis of cyclin D1 and p53 in multiple myeloma: Relationship to proliferative activity and prognostic significance. Med Oncol 2004;21:73-80.

20. Pruneri G, Fabris S, Baldini L, Carboni N, Zagano S, Colombi MA, et al. Immunohistochemical analysis of cyclin D1 shows deregulated expression in multiple myeloma with the $\mathrm{t}(11 ; 14)$. Am J Pathol 2000;156:1505-13.

21. Hoyer JD, Hanson CA, Fonseca R, Greipp PR, Dewald GW, Kurtin PJ. The $(11 ; 14)(q 13 ; q 32)$ translocation in multiple myeloma. A morphologic and immunohistochemical study. Am J Clin Pathol 2000;113:831-7.

22. Hoechtlen-Vollmar W, Menzel G, Bartl R, Lamerz R, Wick $M$, Seidel D. Amplification of cyclin D1 gene in multiple myeloma: Clinical and prognostic relevance. $\mathrm{Br} \mathrm{J}$ Haematol 2000;109:30-8.

23. Vasef MA, Medeiros LJ, Yospur LS, Sun NC, McCourty A, Brynes RK. Cyclin D1 protein in multiple myeloma and plasmacytoma: An immunohistochemical study using fixed, paraffin-embedded tissue sections. Mod Pathol 1997; 10:927-32.

24. Lai R, Medeiros LJ, Wilson CS, Sun NC, Koo C, McCourty A, et al. Expression of the cell-cycle-related proteins E2F-1, p53, mdm-2, p21 waf-1, and $\mathrm{Ki}-67$ in multiple myeloma: Correlation with cyclin-D1 immunoreactivity. Mod Pathol 1998;11:642-7.

25. Kumar SK, Rajkumar SV, Dispenzieri A, Lacy MQ, Hayman SR, Buadi FK, et al. Improved survival in multiple myeloma and the impact of novel therapies. Blood 2008;111:2516-20.

26. Ngo BT, Felthaus J, Hein M, Follo M, Wider D, Ihorst G, et al. Monitoring bortezomib therapy in multiple myeloma: Screening of cyclin D1, D2, and D3 via reliable real-time polymerase chain reaction and association with clinico-pathological features and outcome. Leuk Lymphoma 2010;51:1632-42.

How to cite this article: Padhi S, Varghese RG, Ramdas A. Cyclin D1 expression in multiple myeloma by immunohistochemistry: Case series of 14 patients and literature review. Indian J Med Paediatr Oncol 2013;34:283-91.

Source of Support: Nil, Conflict of Interest: None declared. 